\title{
Evaluation of Protein Extraction Methods for Proteomic Analysis of Non-Model Recalcitrant Plant Tissues ${ }^{\dagger}$
}

\author{
Dubravko Pavoković, ${ }^{*}$ Bojana Križnik, and Marijana Krsnik-Rasol \\ Department of Molecular Biology, Division of Biology, Faculty of Science, University of Zagreb, \\ Horvatovac 102a, HR-10000 Zagreb, Croatia
}

RECEIVED SEPTEMBER 11, 2010; REVISED JUNE 2, 2011; ACCEPTED JUNE 14, 2011

\begin{abstract}
Plant tissues contain relatively low amounts of proteins whose extraction is often difficult due to the presence of interfering compounds such as rigid cellulosic cell wall, storage polysaccharides, lipids and other contaminants that can cause protein degradation or modification. Therefore it is important to optimize protein extraction and to establish a robust protocol for two-dimensional gel electrophoresis (2-DE) and downstream processing. In this study, acetone, trichloroacetic acid/acetone and Tris-buffered phenol/methanol extraction protocols were evaluated on non-model and recalcitrant plants: a Beta vulgaris $\mathrm{L}$. in vitro cell line, Mammillaria gracilis Pfeiff. in vitro plants and Sempervivum tectorum L. leaves. Although phenol extraction was more time-consuming than the other two methods, it gave almost two-fold higher protein yield, and spectral analysis showed less contamination. SDS-PAGE, 2-DE and bioinformatic analysis showed that protein extraction using phenol was superior to the other two methods, providing more protein bands or spots on the gels and less proteolysis. These results lead to the conclusion that the phenol method is the most suitable protein extraction method for these non-model and recalcitrant plant tissues. (doi: 10.5562/cca1804)
\end{abstract}

Keywords: electrophoresis, mass spectrometry, phenol, plant proteomics, protein extraction, trichloroacetic acid

\section{INTRODUCTION}

Chemical and technological advances have contributed to the emergence of high-throughput methods that allow analysis of an organism's entire complement of genes (genomics), mRNAs (transcriptomics) and proteins (proteomics). Two-dimensional polyacrylamide gel electrophoresis (2-DE), pioneered by O'Farrell, coupled to mass spectrometry (MS), is one of the most powerful proteomic tools for the separation, quantification and identification of proteins. ${ }^{1}$ Effective protein extraction and solubilization are absolutely essential for good and reproducible 2-DE results and should yield several thousands of well-resolved proteins. ${ }^{2}$

Generally, plants are regarded as "difficult" or recalcitrant tissues for the preparation of protein samples due to their low protein content; abundance of cell wall and vacuoles, which account for most of the cell mass; presence of proteases and oxidative enzymes; and high levels of polysaccharides, lipids, and phenolic and other secondary metabolites. ${ }^{3}$ On 2-DE gels, such contaminants cause horizontal and vertical streaking and smearing, and they reduce protein resolution. ${ }^{4}$
The most frequently used protocols for extraction of plant proteins involve a precipitation step, which should separate proteins from interfering compounds. Chemicals frequently used for this purpose are acetone, trichloroacetic acid (TCA)/acetone, and Trisbuffered phenol; this protein extraction is generally followed by methanol/ammonium acetate precipitation (phenol) ${ }^{5-7}$ Proteins from several plant species such as banana, avocado, orange fruits, grapevine leaves and tomato pollen have been successfully extracted using TCA/acetone or using phenol, and therefore are the methods of choice for recalcitrant plant tissues. ${ }^{4,5,8}$ As the final step in the procedure, precipitated proteins are resolubilized in buffer. This three-step procedure has several goals: to disrupt macromolecular interactions in order to yield monomeric polypeptide chains, to prevent the modification of proteins in the solubilization medium, to remove substances that interfere with 2-DE and to keep proteins in solution during 2-DE. ${ }^{9}$ As no single protein extraction protocol can capture the full proteome, the protocol must be optimized for each tissue and for particular research objectives. $^{2}$

\footnotetext{
$\dagger$ Presented at the $10^{\text {th }}$ Congress of the Croatian Society of Biochemistry and Molecular Biology held in Opatija, Croatia, September 15-18, 2010.

* Author to whom correspondence should be addressed. (E-mail: dubravko@zg.biol.pmf.hr)
} 
Most method development for proteomic analysis has focused on a few model organisms useful in basic research, such as Arabidopsis and Drosophila, but it has neglected "non-model" organisms that are important for the food and pharmaceutical industries. ${ }^{10}$ In addition, some features and processes, like crassulacean acid metabolism (CAM) photosynthesis or production of flavonoids, are unique to these plant species or families and cannot be studied using model plants. ${ }^{10}$ For nonmodel plants, robust and reproducible protocols to prepare proteins for 2-DE must be developed before proteomic analyses can be carried out.

Here we compare the performance of acetone, TCA/acetone, and phenol extraction methods on three non-model plant species regarded as recalcitrant for protein extraction: the sugar beet $\mathrm{N}$ cell line (Beta vulgaris L.), cactus Mammillaria gracilis Pfeiff., and common houseleek (Sempervivum tectorum L.). We analyzed protein yield and purity of protein samples prior to 2-DE by scanning their UV/VIS/IR absorbance spectra and by performing SDS-PAGE. Then 2-DE was carried out and the gels were analyzed using bioinformatics to determine the best extraction protocol for these recalcitrant tissues.

\section{EXPERIMENTAL}

\section{Plant Materials}

Sugar beet $\mathrm{N}$ cell line (Beta vulgaris L.) and Mammillaria gracilis Pfeiff. plants were grown in vitro in PG0 and Murashige and Skoog medium, respectively. ${ }^{6,11}$ The growth chamber was maintained at $22{ }^{\circ} \mathrm{C}$, under a $16 \mathrm{~h}$ photoperiod $\left(80 \mu \mathrm{mol}\right.$ photons $\left.\mathrm{m}^{-2} \mathrm{~s}^{-1}\right)$. Sempervivum tectorum L. was grown locally in a nearby park (Horvatovac, Zagreb, Croatia). Tissues were collected, weighed, frozen in liquid nitrogen and stored at $-80{ }^{\circ} \mathrm{C}$.

\section{Protein Extraction Methods}

For all protein extraction methods, frozen tissues were ground to fine powder in liquid nitrogen using a precooled mortar and pestle.

\section{Acetone Protocol}

Tissue powder $(1.5 \mathrm{~g})$ was resuspended in $1.5 \mathrm{ml}$ of ice-cold Tris- $\mathrm{HCl}$ buffer $(\mathrm{pH}=8.0)$ containing 500 mmol dm ${ }^{-3}$ sucrose, ascorbic acid $\left(\gamma=1 \mathrm{~g} \mathrm{dm}^{-3}\right)$, cysteine- $\mathrm{HCl}\left(\gamma=1 \mathrm{~g} \mathrm{dm}^{-3}\right)$, and polyvinylpyrrolidone $(\gamma$ $\left.=0.1 \mathrm{~g} \mathrm{dm}^{-3}\right) .{ }^{12}$ Cell debris was removed by centrifugation at $20800 \mathrm{~g}$ at $4{ }^{\circ} \mathrm{C}$ for $15 \mathrm{~min}$. The supernatant was centrifuged again at $20800 \mathrm{~g}$ at $4{ }^{\circ} \mathrm{C}$ for $60 \mathrm{~min}$. Proteins were precipitated by adding two volumes of ice-cold acetone and stored overnight at $-20{ }^{\circ} \mathrm{C}$. Pro- teins were pelleted by centrifuging samples at $20800 \mathrm{~g}$ at $4{ }^{\circ} \mathrm{C}$ for $10 \mathrm{~min}$. The pellet was washed twice with acetone and centrifuged as above. Acetone was discarded, and pellets were dried under air at room temperature.

\section{TCA/Acetone Protocol}

This procedure was modified from a published TCA protocol. ${ }^{13}$ Tissue powder $(1.5-5 \mathrm{~g})$ was dissolved in $3-5 \mathrm{ml}$ of ice-cold extraction buffer consisting of 175 mmol dm-3 Tris/HCl $(\mathrm{pH}=8.8), \operatorname{SDS}\left(\gamma=50 \mathrm{~g} \mathrm{dm}^{-3}\right)$, glycerol $(\varphi=15 \%)$ and 2-mercaptoethanol $(\varphi=0.07$ $\%$ ). Cell debris was removed by centrifuging at $500 \mathrm{~g}$ at $4{ }^{\circ} \mathrm{C}$ for $15 \mathrm{~min}$. The supernatant was transferred to a new tube, and proteins were precipitated by adding four volumes of ice-cold acetone containing trichloracetic acid $(\varphi=10 \%)$, and 2-mercaptoethanol $(\varphi=0.07 \%)$. Samples were stored at $-20{ }^{\circ} \mathrm{C}$ for at least $1 \mathrm{~h}$. Pellets were obtained by centrifugation at $15000 \mathrm{~g}$ at $4{ }^{\circ} \mathrm{C}$ for $45 \mathrm{~min}$, and washed three times with an ice-cold solution of 2-mercaptoethanol $(\varphi=$ $0.07 \%)$ in water/acetone $(\varphi=20 \%)$. Pellets were centrifuged at $15000 \mathrm{~g}$ for $15 \mathrm{~min}$ between washes. Supernatants were discarded, and pellets were dried under air at room temperature.

\section{Phenol/Methanol Protocol}

The phenol extraction protocol was performed following a published procedure. ${ }^{7}$ Tissue powder $(1.5 \mathrm{~g})$ was resuspended in $3 \mathrm{ml}$ of extraction buffer containing $500 \mathrm{mmol} \mathrm{dm}^{-3}$ Tris $(\mathrm{pH}=8.0), 50 \mathrm{mmol} \mathrm{dm}^{-3}$ EDTA, $700 \mathrm{mmol} \mathrm{dm}^{-3}$ sucrose, $100 \mathrm{mmol} \mathrm{dm}^{-3} \mathrm{KCl}$ and 2-mercaptoethanol $(\varphi=0.07 \%)$. Samples were vortexed and incubated by shaking for $10 \mathrm{~min}$ on ice. Afterwards, an equal volume of Tris-buffered phenol $(\mathrm{pH}=8.0)$ was added, and solutions were incubated on a shaker for $10 \mathrm{~min}$ at room temperature. To eliminate cell debris, samples were centrifuged at $5500 \mathrm{~g}$ at $4{ }^{\circ} \mathrm{C}$ for $10 \mathrm{~min}$. The upper phenolic phase was transferred to a new tube, and back-extracted with $3 \mathrm{ml}$ of extraction buffer. Samples were incubated on a shaker for 3 min, vortexed and centrifuged at $3200 \mathrm{~g}$ at $4{ }^{\circ} \mathrm{C}$ for 20 min. The phenol phase was carefully transferred to a new tube and four volumes of precipitation buffer, consisting of $100 \mathrm{mmol} \mathrm{dm}{ }^{-3}$ ammonium acetate in ice-cold methanol, were added. Tubes were mixed by inversion, and samples were incubated overnight at $20{ }^{\circ} \mathrm{C}$. Proteins were pulled down by centrifugation at $3200 \mathrm{~g}$ at $4{ }^{\circ} \mathrm{C}$ for $15 \mathrm{~min}$. After centrifugation, the pellets were washed three times with ice-cold precipitation buffer and finally with ice-cold acetone. After each washing step, the sample was centrifuged for 5 min at $5500 \mathrm{~g}$ at $4{ }^{\circ} \mathrm{C}$. Finally, pellets were dried under air at room temperature. 

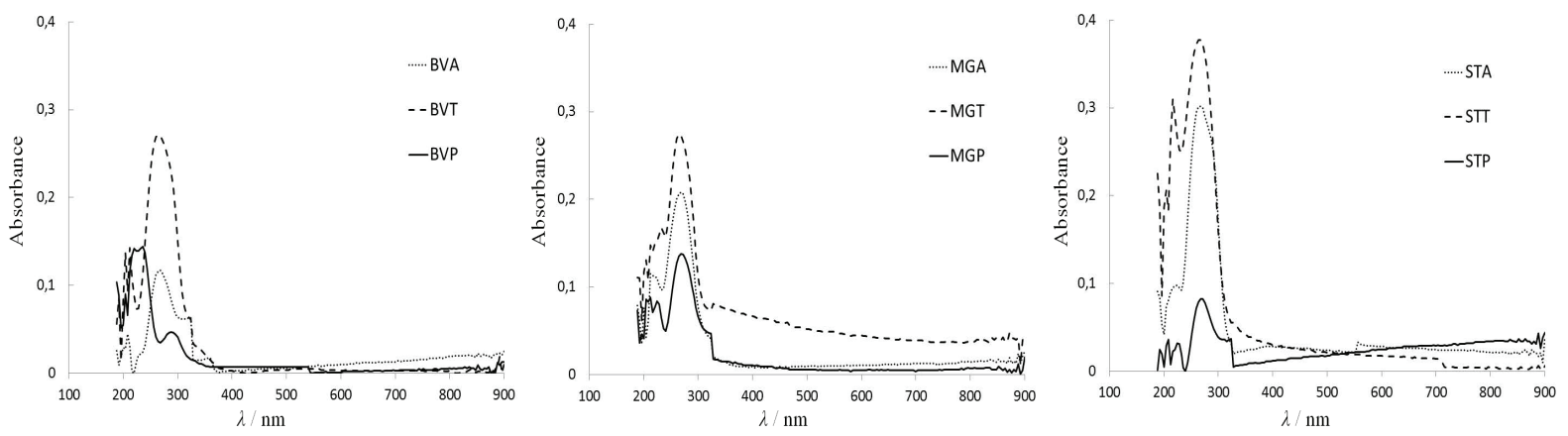

Figure 1. UV-Vis-IR spectra of protein samples solubilized in IEF buffer. BVA - B. vulgaris acetone, BVT - B. vulgaris TCA/acetone, BVP - B. vulgaris phenol, MGA - M. gracilis acetone, MGT - M. gracilis TCA/acetone, MGP - M. gracilis phenol, STA - S. tectorum acetone, STT - S. tectorum TCA/acetone, STP - S. tectorum phenol.

\section{Protein Solubilization and Quantification}

Protein pellets were dissolved in isoelectric focusing (IEF) buffer consisting of $9 \mathrm{~mol} \mathrm{dm}^{-3}$ urea, 3-[(3cholamidopropyl)dimethylammonio]-1-propanesulfonate (CHAPS, $\gamma=20 \mathrm{~g} \mathrm{dm}^{-3}$ ) and dithiothreitol (DTT, $\varphi=$ $0.3 \%)$. Samples were incubated in IEF buffer for at least $1 \mathrm{~h}$ at room temperature. Samples were sonicated three times for $15 \mathrm{~s}$ in an ice bath and centrifuged at $14000 \mathrm{~g}$ for $5 \mathrm{~min}$. Protein concentration was determined by the Bradford method using a UV/Vis spectrophotometer UV-4 (Unicam, UK) and BSA as a standard. ${ }^{14}$

\section{Recording Protein Spectra}

To determine the level of residual contamination in the protein extracts, UV, visible and infra-red absorbance spectra were recorded in the range from 190 to $900 \mathrm{~nm}$. Equal amounts of total protein were loaded in the spectrophotometer, based on the concentrations determined as described above.

\section{Electrophoresis}

Sodium dodecyl sulfate polyacrylamide gel electrophoresis (SDS-PAGE) was performed in a mini vertical gel system $(12 \% \mathrm{~T}, 2.67 \% \mathrm{C})$ with the buffer system of Laemmli. ${ }^{6,15}$ Samples were run for $15 \mathrm{~min}$ in a stacking gel at $90 \mathrm{~V}$ and for $50 \mathrm{~min}$ in a resolving gel at $180 \mathrm{~V}$. IEF was performed in 17-cm IPG strips (nonlinear $\mathrm{pH}$ gradient, $\mathrm{pH}=3$ to $\mathrm{pH}=10$ ) in the IPGphor system (GE Healthcare, USA). IPG strips were rehydrated overnight in $300 \mu \mathrm{L}$ of IEF buffer containing $300 \mu \mathrm{g}$ of proteins. IEF was carried out using the following stepped gradient: $0-500 \mathrm{~V}$ over $1 \mathrm{~h}, 500-1000 \mathrm{~V}$ over $1 \mathrm{~h}, 1000-8000$ $\mathrm{V}$ over $1 \mathrm{~h}$, and then $8000 \mathrm{~V}$ step until a total run of $45000 \mathrm{~V}$ h. IPG strips were stored at $-80{ }^{\circ} \mathrm{C}$ until use. Before the second dimension, the strips were equilibrated for $15 \mathrm{~min}$ in equilibration buffer $\left(6 \mathrm{~mol} \mathrm{dm}^{-3}\right.$ urea, $375 \mathrm{mmol} \mathrm{dm}^{-3}$ Tris-HCl $(\mathrm{pH}=8.8), \operatorname{SDS}(\gamma=$ $\left.20 \mathrm{~g} \mathrm{dm}^{-3}\right)$, glycerol $\left.(\varphi=20 \%)\right)$ containing $100 \mathrm{mmol}$ $\mathrm{dm}^{-3}$ DTT and then again for $15 \mathrm{~min}$ in the same buffer but with $125 \mathrm{mmol} \mathrm{dm}^{-3}$ iodoacetamide instead of DTT. Equilibrated IPG strips were laid on top of the polyacrylamide gel $(12 \% \mathrm{~T}, 2.67 \% \mathrm{C})$ in a large vertical electrophoresis system, and agarose $\left(\gamma=5 \mathrm{~g} \mathrm{dm}^{-3}\right)$ was cast on top to hold the strips in place. Electrophoresis was performed at $100 \mathrm{~V}$ for $30 \mathrm{~min}$ and then at $220 \mathrm{~V}$ until the bromophenol blue run off the gel.

\section{Gel Staining, Image Acquisition and Analysis}

Protein spots were visualized by Commassie Brilliant Blue R-250 (CBB) or by silver staining. ${ }^{16}$ After protein visualization, gels were scanned on a flatbed scanner (HP, USA) at a resolution of $600 \mathrm{dpi}$ and analyzed with Proteomweaver 2.2 (Definiens, Germany). Protein spots were detected using the following parameters: intensity limit, 10000; contrast limit, 50; and radius limit, 10.

\section{RESULTS AND DISCUSSION}

In this study, we compared three different protein extraction methods on a $B$. vulgaris cell line, M. gracilis in vitro plants and $S$. tectorum leaves, to determine which method gives more clearly resolved proteins and fewer interfering substances. We determined yields of the proteins after loading equal amounts $(1.5 \mathrm{~g})$ of starting material into the extraction procedure (Table 1). After precipitation and solubilization in the same volume of

Table 1. Comparison of protein yield from different organisms using different extraction methods

\begin{tabular}{lccc}
\hline & \multicolumn{3}{c}{ Protein concentration $\left(\mathrm{mg} \mathrm{cm}^{-3}\right)$} \\
\cline { 2 - 4 } Species & Acetone & TCA/acetone & Phenol \\
B. vulgaris & NA & $0.444 \pm 0,276$ & $1.081 \pm 0.253$ \\
M. gracilis & NA & $0.229 \pm 0.083$ & $1.019 \pm 0.298$ \\
S. tectorum & NA & $0.137 \pm 0.042$ & $0.966 \pm 0.241$ \\
\hline
\end{tabular}




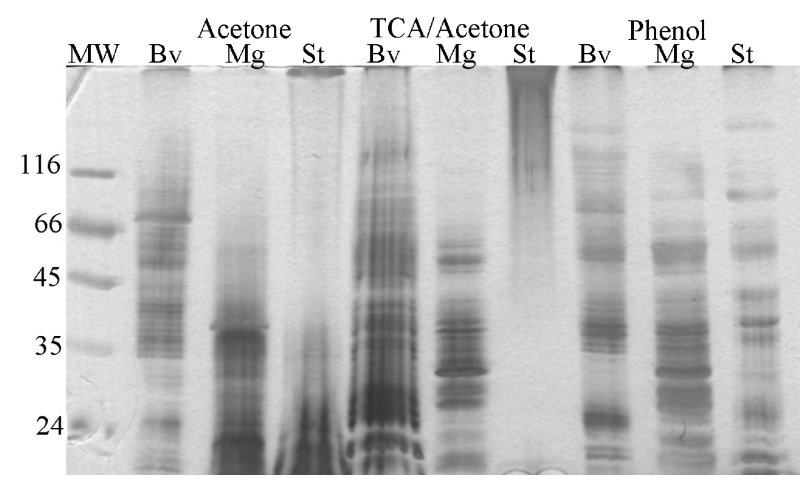

Figure 2. SDS-PAGE of protein samples extracted using different methods and run on $12 \%$ gels. An equal amount of protein $(10 \mu \mathrm{g})$ was loaded in each lane. Proteins were visualized with silver staining. MW - molecular weight markers in $\mathrm{kDa} ; \mathrm{Bv}-$ B. vulgaris, $\mathrm{Mg}-$ M. gracilis, $\mathrm{St}-\mathrm{S}$. tectorum .

IEF buffer, the phenol extraction method gave higher protein concentration than the TCA/acetone method. Similar results were found for protein extracts of tomato pollen and grapevine leaves. ${ }^{4-5}$ Less complete solubilization of protein pellets and the acidity of TCA, which leads to proteolysis, may be responsible for the lower yield of proteins using TCA/acetone. ${ }^{2}$ On the other hand, in the case of Brassica sp. seeds, TCA/acetone precipitation step gave higher protein yield than phenol precipitiation. ${ }^{17}$ The acetone extraction method could not be compared with the other two methods because the protein concentration of the samples was measured before the precipitation and solubilization steps.

In order to estimate the amount of residual contaminants in the resolubilized protein that might interfere with IEF, we compared absorption spectra of the final protein samples in IEF buffer in the UV/Vis/IR range from 190 to $900 \mathrm{~nm}$ (Figure 1). The majority of absorption was in the UV range of the spectrum, from
190 to $350 \mathrm{~nm}$. Samples prepared using TCA/acetone precipitation gave the greatest absorption in this region, followed by samples prepared using acetone precipitation. Samples obtained using phenol extraction gave the lowest absorbance in this region, except in the case of $B$. vulgaris. The absorption maximum at $\approx 190 \mathrm{~nm}$ comes from polysaccharides, maxima at 240-290 and 340-380 nm come from polyphenols like flavonoids and the maximum at $260 \mathrm{~nm}$ confirms the presence of DNA and RNA. ${ }^{18,19}$ The phenol method was the most effective for removal of unwanted interfering substances from the protein samples. This method was also effective for removing interfering compounds from banana, potato and apple. ${ }^{20}$ Phenol extraction is based on separation of macromolecules into organic and aqueous phases. The aqueous phase preferentially dissolves nucleic acids, carbohydrates and cell debris, while the phenolic phase carries proteins and lipids. ${ }^{21}$ Proteins from the phenolic phase are then precipitated with methanol and ammonium acetate. ${ }^{7}$ TCA/acetone coprecipitates interfering substances like DNA by a mechanism that irreversibly incorporates DNA in protein precipitates, yielding DNA-protein aggregates. ${ }^{22}$ Acetone, in contrast, tends to coprecipitate different types of lipids with proteins. These interfering compounds increase UV absorption.

The quality of the protein samples was further evaluated by 1-D SDS-PAGE (Figure 2). Gels were silver stained in order to visualize not only proteins but also DNA and RNA contaminants, which cannot be visualized by $\mathrm{CBB}$ or Sypro Ruby stain. ${ }^{16}$ The three tested methods differed in the banding patterns and band resolution obtained. The phenol method gave the clearest lanes with the highest resolution of separated protein bands. In addition, it gave the greatest number of 1-D bands, which suggests that that the loss of proteins was lower than with the other methods. The quality of samples obtained by the acetone and TCA/acetone methods varied with the plant, but in all
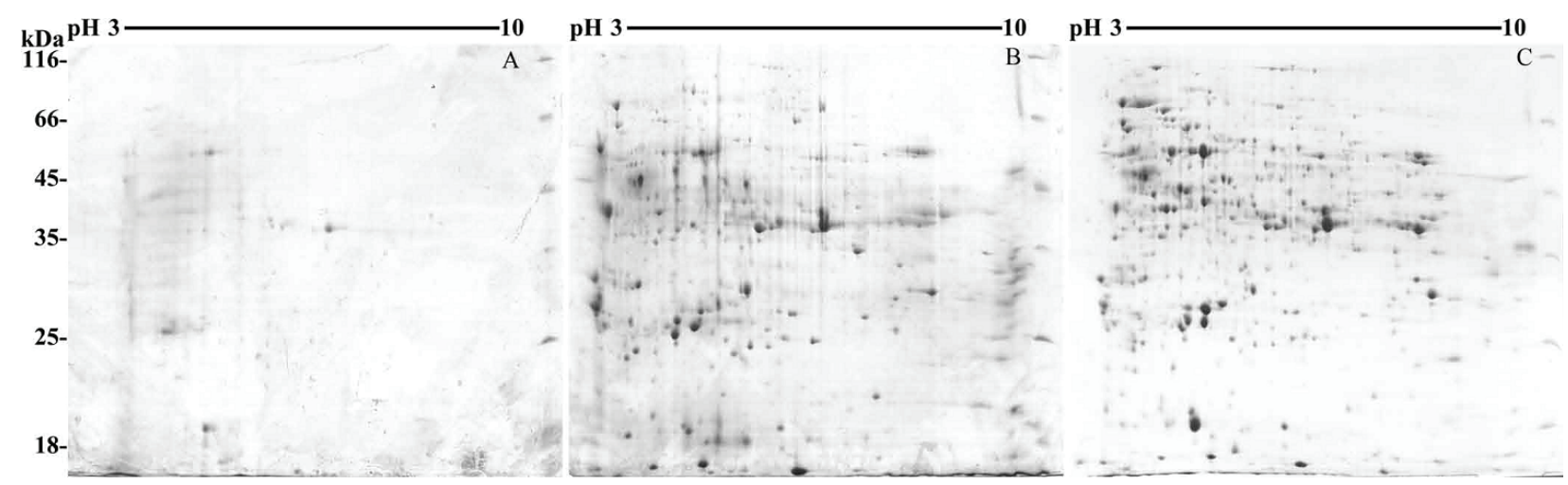

Figure 3. 2-DE gels of protein extracts from B. vulgaris obtained by the acetone (A), TCA/acetone (B) or phenol (C) methods. Proteins $(300 \mu \mathrm{g})$ were separated on $17-\mathrm{cm}$ IPG strips over a nonlinear $\mathrm{pH}$ range of 3-10 and then separated by mass on $12 \%$ polyacrylamide gels. Gels were stained with Coomassie Brilliant Blue. The numbers on the left represent molecular weight of protein markers in $\mathrm{kDa}$ and the numbers on the top of the gels show the $\mathrm{pH}$ area of the IPG strip. 
Table 2. Comparison of the number of protein spots detected on 2-DE gels following different extraction methods

\begin{tabular}{|c|c|c|c|c|c|c|c|c|c|}
\hline \multirow[b]{3}{*}{ Size range $(\mathrm{kDa})$} & \multicolumn{9}{|c|}{ Number of spots detected } \\
\hline & \multicolumn{3}{|c|}{ Acetone } & \multicolumn{3}{|c|}{ TCA/Acetone } & \multicolumn{3}{|c|}{ Phenol } \\
\hline & $\mathrm{Bv}$ & $\mathrm{Mg}$ & St & $\mathrm{Bv}$ & $\mathrm{Mg}$ & St & $\mathrm{Bv}$ & $\mathrm{Mg}$ & St \\
\hline$+116-66$ & 0 & 3 & 0 & 36 & 4 & 1 & 60 & 43 & 32 \\
\hline $65-25$ & 42 & 8 & 2 & 243 & 99 & 1 & 384 & 259 & 218 \\
\hline $24-0$ & 27 & 0 & 16 & 83 & 48 & 2 & 88 & 76 & 66 \\
\hline Total & 69 & 11 & 18 & 362 & 151 & 4 & 512 & 378 & 316 \\
\hline$(+116-25):(24-0)$ & 1.56 & ND & 0.13 & 3.36 & 2.15 & 1 & 4.81 & 3.97 & 3.79 \\
\hline
\end{tabular}

cases was lower than with the phenol method (Figure 2 ). The extensive smearing observed in $S$. tectorum acetone and TCA/acetone samples and in B. vulgaris TCA/acetone samples confirms the presence of nucleic acids and polysaccharides. Similarly, interfering substances in samples from Hypericum perforatum organs obtained after acetone and TCA/acetone precipitation produced low-quality SDS-PAGE results. $^{23}$

We performed IEF with $300 \mu \mathrm{g}$ of the proteins, followed by 2-DE (Figures 3-5). Differences were observed in both the number and resolution of protein spots. The acetone precipitation produced the lowest number of protein spots after CBB staining in all three plants tested (Figures $3 \mathrm{a}, 4 \mathrm{a}, 5 \mathrm{a}$ ). It gave poor results even with $B$. vulgaris, despite the promising 1-D SDSPAGE results (Figure 2). The TCA/acetone method gave intermediate results (Figures $3 b, 4 b, 5 b$ ), while software analysis detected the highest number of protein spots in the gels after phenol extraction (Figures $3 c, 4 c, 5 c$; Table 2). The extent of proteolysis in the different methods was estimated by examining the distribution of spots according to their molecular weight and calculating the ratio between highmolecular-weight spots and low-molecular-weight spots (Table 2). The high ratio for phenol suggests that this method more efficiently preserved proteins, inhibiting their hydrolysis, while TCA/acetone was less effective. Prolonged exposure of the proteins to acidic
TCA may contribute to protein hydrolysis. Due to the low number of protein spots in gels obtained with the acetone method, it was difficult to estimate the extent of proteolysis.

The quality of 2-DE gels is influenced by contaminants and interfering compounds that remain in the IEF buffer. For example, the maximum concentration of salts for effective IEF is $50 \mathrm{mmol} \mathrm{dm}^{-3} .^{24}$ It seems that for particularly recalcitrant tissues like the ones tested here, acetone and TCA/acetone precipitation do not sufficiently remove nucleic acids, carbohydrates and polyphenols, which cause precipitation, bad focusing and protein streaking. ${ }^{20,22,23}$ Another issue with the TCA/acetone and acetone precipitation methods is the low yield of extracted proteins: to produce enough proteins from $M$. gracilis and $S$. tectorum for 2-DE, these methods would require up to 4 times more of the starting material than the phenol method (data not shown). Using much more starting material also increases the amount of contaminants in the samples.

In the present paper we managed to visualize around 300-500 protein spots per gel using the phenol extraction method and CBB staining; these spots represent only the most abundant proteins in the cell. Not surprisingly, there is great interest in analyzing lowcopy cellular proteins such as phosphoproteins and transcription factors, and the proteome of subcellular components like nuclei, chloroplasts, lysosomes, mem-

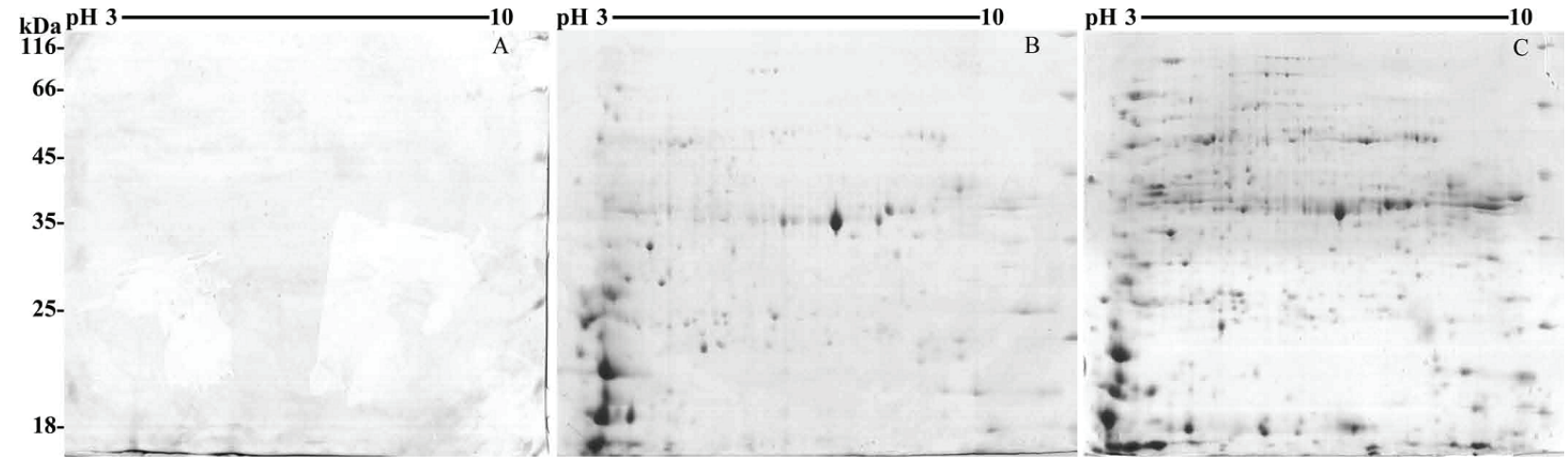

Figure 4. 2-DE gels of protein extracts from M. gracilis. See the legend to Figure 3 for further information. 


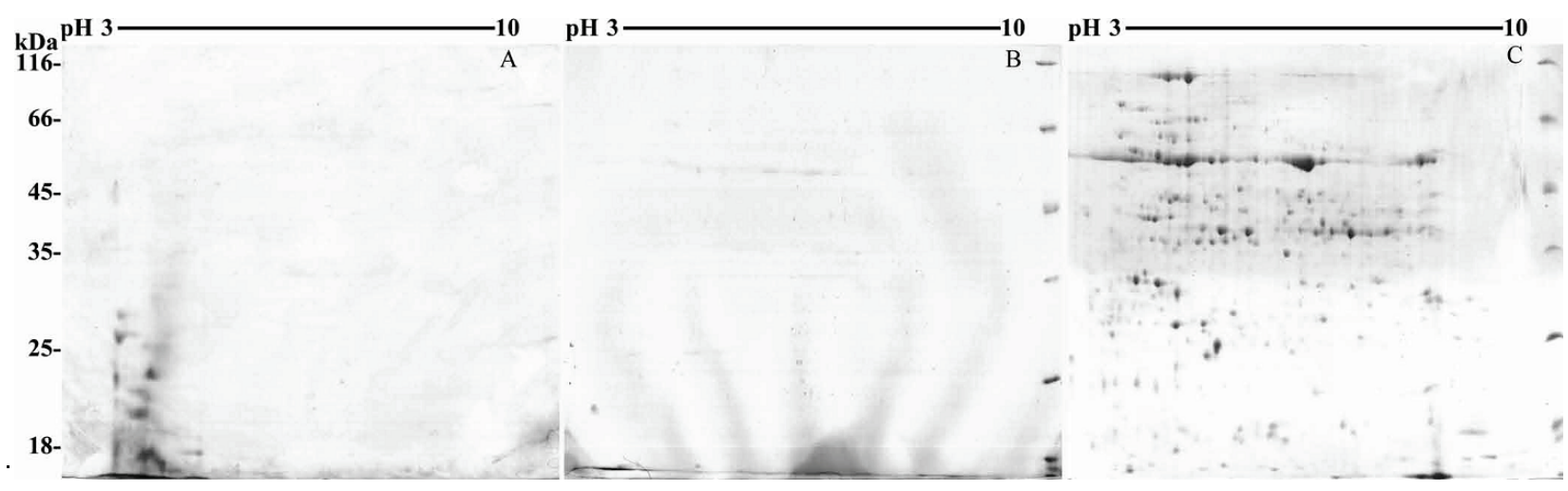

Figure 5. 2-DE gels of protein extracts from S. tectorum. See the legend to Figure 3 for further information.

branes and the cell wall. The phosphoprotein fraction of the proteome can be enriched using immobilized metal affinity chromatography, metal oxide affinity chromatography (MOAC) and covalent methods. ${ }^{25}$ MOAC, which is based on adsorption of phosphoproteins to $\mathrm{TiO}_{2}$, allowed identification of phosphoproteins involved in the response of Arabidopsis to the plant hormone abscissic acid or to cytokinins. ${ }^{26,27}$ PolyA- and polyU-affinity columns were used to capture previously unidentified low-abundance proteins containing nucleotide-binding motifs from total cell lysate and from chloroplasts. $^{28,29}$ A common strategy to obtain organelles or subcellular fractions is equilibrium density-gradient centrifugation, in which particles are separated according to their physical properties. An alternative approach to isolating organelles involves the use of specific antibodies against the cytoplasmic domain of an organelle transmembrane protein or against a molecular tag inserted into a recombinant protein expressed in the target organelle. $^{30,31}$

The success of a proteomic experiment depends on the correct identification of proteins, which is limited by the publicly available sequence information against which trypsin peptides can be matched. This information is most abundant for species whose genomes have been fully sequenced, such as Arabidopsis, rice, maize or soybean. For sugar beet, the genome is nearing completion, but for Mammilaria or Sempervivum, few, if any, gene sequences exist. An approach to remedy this data deficit is to increase protein identification from unsequenced organisms. This involves matching MS/MS data against protein sequences of an evolutionarily closely related organism or extracting amino acid sequences from MS/MS spectra for de novo peptide sequencing, which is database-independent. ${ }^{32,33}$

\section{CONCLUSION}

The results of this study have shown that the phenol method, although more laborious and time-consuming, is in every aspect tested superior to acetone and
TCA/acetone methods for protein extraction from $B$. vulgaris, $M$. gracilis and $S$. tectorum samples. The phenol method resulted in the highest protein yield and the least contamination of protein samples, which is important since removal of interfering compounds is crucial for SDS-PAGE, IEF and 2-DE. With the phenol method, the number of detected protein spots in the 2-DE gels was highest and the extent of protein hydrolysis the lowest. Therefore we propose the phenol extraction procedure as optimal for these tissues. This is, to our knowledge, the first attempt to establish a proteome map of the Sempervivum species, which has not yet been studied in detail at the protein level.

Acknowledgements. This work was supported by a grant no. 119-1191196-1200 to prof. dr. sc. Marijana Krsnik-Rasol and a grant "Life under stress: molecular components and mechanisms of plant response to drought and salinity stress" to prof. dr. sc. Marijana Krsnik-Rasol and prof. Dudy Bar-Zvi. Grants are from the Ministry of Science, Education and Sports of the Republic of Croatia. We are greatly indebted to doc. dr. sc. Biljana Balen for providing M. gracilis tissues.

\section{REFERENCES}

1. P. H. O'Farrell, J. Biol. Chem. 250 (1975) 4007-4021.

2. A. M. Maldonado, S. Echevarria-Zomeno, S. Jean-Baptiste, M. Hernandez and J. V. Jorrin-Novo, J. Proteomics 71 (2008) 461-472.

3. T. Isaacson, C. M. Damasceno, R. S. Saravanan, Y. He, C. Catala, M. Saladie, and J. K. Rose, Nat. Protoc. 1 (2006) 769774.

4. N. Jellouli, A. B. Salem, A. Ghorbel, and H. B. Jouira, J. Integr. Plant Biol. 52 (2010) 933-940.

5. R. S. Saravanan and J. K. C. Rose, Proteomics 4 (2004) 2522-2532.

6. D. Pavoković, I. Šola, D. Hège, and M. Krsnik -Rasol, Acta Bot. Croat. 66 (2007) 127-134.

7. M. Faurobert, E. Pelpoir, and J. Chaïb, Methods Mol. Biol. (Clifton, N.J.). 355 (2007) 9-14.

8. I. S. Sheoran, A. R. S. Ross, D. J. H. Olson, and V. K. Sawhney, Plant Sci. 176 (2009) 99-104.

9. T. Rabilloud, Methods Mol. Biol. (Clifton, N.J.) 519 (2009) 19-30.

10. S. C. Carpentier, B. Panis, A. Vertommen, R. Swennen, K. Sergeant, J. Renaut, K. Laukens, E. Witters, B. Samyn, and B. Devreese, Mass Spectrom. Rev. 27 (2008) 354-377. 
11. B. Balen, M. Tkalec, D. Pavokovic, B. Pevalek-Kozlina, and M. Krsnik-Rasol, J. Plant Growth Regul. 28 (2009) 36-45.

12. R. C. Staples, and M. A. Stahmann, Phytopathology 54 (1964) 760-764.

13. G. Caruso, C. Cavaliere, P. Foglia, R. Gubbiotti, R. Samperi, and A. Lagana, Plant Sci. 177 (2009) 570-576.

14. M. M. Bradford, and W. L. Williams, Fed. Proc. 35 (1976) 274-274.

15. U. K. Laemmli, Nature 227 (1970) 680-685.

16. H. Blum, H. Beier and H. J. Gross, Electrophoresis 8 (1987) 93-99.

17. V. Devouge, H. Rogniaux, N. Nesi, D. Tessier, J. Gueguen, and C. Larre, J. Proteome Res. 6 (2007) 1342-1353.

18. P. Richardson, Brittonia 42 (1990) 115-115.

19. L. Shi, K. Chen, Q. Dong, J. Fang, and K. Ding, Front. Chem. China 3 (2008) 209-212.

20. S. C. Carpentier, E. Witters, K. Laukens, P. Deckers, R. Swennen, and B. Panis, Proteomics 5 (2005) 2497-2507.

21. S. P. Rodrigues, J. A. Ventura, R. B. Zingali, and R. M. B. Fernandes, Phytochem. Anal. 20 (2009) 456-464.

22. P. Antonioli, A. Bachi, E. Fasoli, and P. G. Righetti, J. Chromatogr. A 1216 (2009) 3606-3612.

23. K. Karppinen, E. Taulavuori, and A. Hohtola, Mol. Biotechnol. 46 (2010) 219-226.
24. P. A. Kirkland, J. Busby, S. Stevens, and J. A. Maupin-Furlow, Anal. Biochem. 351 (2006) 254-259.

25. J. D. Dunn, G. E. Reid, and M. L. Bruening, Mass Spectrom. Rev. 29 (2010) 29-54.

26. K. G. Kline, G. A. Barrett-Wilt, and M. R. Sussman, P. Natl. Acad. Sci. USA 107 (2010) 15986-15991.

27. M. Erný, F. Dyka, J. Bobál'Ová, and B. Brzobohatý, J. Exp. Bot. 62 (2011) 921-937.

28. Y. Xu, B. C. Wang, and Y. X. Zhu, Biochem. Bioph. Res. Co. 358 (2007) 808-812.

29. R. J. Ni, Z. Shen, C. P. Yang, Y. D. Wu, Y. D. Bi, and B. C. Wang, Mol. Biol. Rep. 37 (2010) 637-641.

30. J. R. Yates, A. Gilchrist, K. E. Howell, and J. J. M. Bergeron, Nat. Rev. Mol. Cell. Biol. 6 (2005) 702-714.

31. A. P. Kausch, T. P. Owen Jr, S. Narayanswami, and B. D. Bruce, BioTechniques 26 (1999) 336-343.

32. J. Grossmann, B. Fischer, K. Baerenfaller, J. Owiti, J. M. Buhmann, W. Gruissem, and S. Baginsky, Proteomics 7 (2007) 4245-4254.

33. S. Tanner, Z. X. Shen, J. Ng, L. Florea, R. Guigo, S. P. Briggs, and V. Bafna, Genome Res. 17 (2007) 231-239. 